\begin{tabular}{|c|c|c|}
\hline deCartesian 9 & Jurnal Matematika dan Aplikasi & \\
\hline & deOanterian & \\
\hline$=$ & 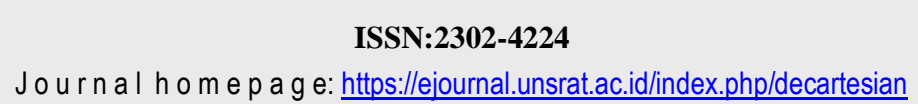 & deCartesian \\
\hline
\end{tabular}

\title{
Pemodelan Biaya Garansi Dua Dimensi Polis FRW (Non-Renewing Free Replacement Warranty) dengan Strategi Penggantian untuk Oil Filter Mobil
}

\author{
Nur Rohman ${ }^{1}$, Tundjung Mahatma ${ }^{1}$, Leopoldus Ricky Sasongko ${ }^{\text {** }}$ \\ ${ }^{1}$ Program Studi Matematika-Fakultas Sains dan Matematika-UKSW, Jln. Diponegoro No. 52-60, Salatiga 50711, Indonesia \\ *Corresponding author: leopoldus.sasongko@ staff.uksw.edu.
}

\begin{abstract}
A B S T R A K
Penelitian ini bertujuan untuk memperoleh model biaya garansi dua dimensi polis non-renewing free replacement warranty dengan strategi penggantian untuk komponen pada mobil yaitu oil filter. Model biaya garansi tersebut melibatkan distribusi bivariat atau copula. Perilaku data bivariat (umur dan penggunaan) kegagalan pertama komponen oil filter mobil dipelajari pada penelitian ini. Kecocokan data bivariat terhadap suatu distribusi bivariat atau copula itu didasarkan pada ukuran statistik Cramèr-von Mises dengan pengujiannya dibantu dengan simulasi parametric bootstrap. Biaya garansi diperoleh berdasarkan model biaya tersebut dan dihitung dengan menggunakan metode mean value theorem for integrals. Hasil penelitian ini berupa model dan biaya garansi dua dimensi polis non-renewing free replacement warranty dengan strategi penggantian untuk oil filter mobil. Model yang terbaik adalah model yang melibatkan copula Clayton dengan distribusi marginal umur adalah distribusi Weibull dan marginal penggunaan adalah disribusi Lognormal. Model tersebut dipilih berdasarkan ukuran statistik Cramèr-von Mises yang relatif kecil dengan p-value terbesar dibanding model-model lain melalui bantuan simulasi parametric bootstrap. Melalui model terbaik tersebut, biaya garansi dihitung dengan menggunakan metode mean value theorem for integrals yang diusulkan dalam penelitian ini. Biaya garansi tersebut diperoleh berdasarkan masa garansi dua dimensi oil filter mobil yang tergantung pada umur dan penggunaannya. Biaya garansi naik sebanding dengan umur dan penggunaan yang meningkat.
\end{abstract}

\author{
INFO ARTIKEL \\ Diterima $\quad: 16$ Desember 2017 \\ Diterima setelah revisi : 8 Januari 2018 \\ Tersedia online $\quad: 31$ Maret 2018
}

\section{Kata Kunci:}

Model Biaya Garansi Dua Dimensi,

Non-Renewing Free Replacement Warranty,

Strategi Penggantian,

Data Bivariat,

Umur dan Penggunaan,

Copula

\section{PENDAHULUAN}

Banyak hal harus dipertimbangkan konsumen sewaktu membeli mobil. Salah satu hal yang penting bagi konsumen adalah bahwa mobil yang akan dibelinya dapat dipergunakan dalam jangka waktu yang panjang dengan jaminan tertentu serta ketersediaan suku cadang yang memadai. Jaminan tersebut dapat diperoleh melalui garansi. Garansi merupakan suatu kontrak antara produsen dan konsumen yang mewajibkan produsen manufaktur untuk memberikan kompensasi (perbaikan, penggantian, pengembalian uang, dsb) kepada konsumen terhadap kegagalankegagalan item atau komponen pada produk yang terjadi selama masa garansi yang ditentukan sejak transaksi jual-beli produk [1].

Garansi selalu berkaitan erat dengan polis yang diterapkan di dalam garansi. Hal-hal mengenai taksonomi, kategori, jenis, dan definisi berbagai polis garansi dijabarkan lengkap oleh [2]. Salah satu polis garansi yang sering diterapkan pada kendaraan bermotor di Indonesia adalah polis non-renewing free replacement warranty (atau disebut polis FRW). Dalam polis FRW, produsen berkewajiban melakukan perbaikan atau penggantian satu atau lebih komponen pada produk yang gagal dalam masa garansi dengan biaya gratis pada konsumen [1]. Apabila terjadi kegagalan komponen, setelah dilakukan pembetulan atau pemulihan (rectification) pada komponen yang gagal, masa garansi tidak diperbarui atau tetap berakhir seperti yang ditentukan di dalam kontrak garansi saat transaksi jual-beli pertama kali [1]. Berdasarkan hal-hal tersebut, polis garansi mempengaruhi biaya garansi yang ditanggung oleh produsen. 
Beberapa peneliti telah membahas hal mengenai garansi dua dimensi polis FRW dengan strategi penggantian. Salah satu peneliti tersebut adalah Baik, dkk., pada [3] dimana, selain membahas pada strategi penggantian, dibahas juga strategi perbaikan minimum sebagai pembanding model biaya garansi dengan strategi penggantian. Model yang diusulkan oleh [3] adalah model yang melibatkan distribusi Weibull yang diusulkan oleh Lu-Bhattacharyya pada [4]. Sasongko pada [1] melanjutkan penelitian oleh [3] untuk model dengan strategi penggantian yang melibatkan fungsi copula. Berdasarkan [1], model yang melibatkan copula menjadi lebih variatif sebagai akibat fungsi copula dapat memodelkan marginal-marginal yang berasal dari keluarga-keluarga distribusi yang berbeda

Penelitian ini mempertimbangkan pemberian garansi oil filter mobil yang non-repairable. Data diperoleh dari salah satu dealer mobil di Jawa Tengah. Data tersebut berkaitan dengan penggantian komponen oil filter dari salah satu brand mobil di dealer tersebut. Data penggantian oil filter berkisar pada awal tahun 2011 sampai awal tahun 2016 untuk brand mobil yang sama. Data tersebut terdiri atas umur dan penggunaan saat oil filter akan diganti dengan oil filter yang baru. Penelitian ini bertujuan untuk memperoleh model dan biaya garansi dua dimensi polis FRW dengan strategi penggantian untuk komponen oil filter tersebut. Hal penting mengenai perolehan model tersebut dalam penelitian ini dapat menjadi kontribusi keilmuan bagi berbagai pihak seperti produsen mobil, terkhusus atau dapat juga produsen oil filter mobil, dan peneliti maupun pengamat kebijakan garansi dua dimensi.

\section{DASAR TEORI DAN METODE PENELITIAN 2.1. Biaya Garansi}

Biaya garansi dinyatakan oleh peubah acak kerugian aggregat $A$ yaitu

$$
A=\sum_{i=1}^{N} L_{i}=L_{1}+L_{2}+\cdots+L_{N}
$$

dengan $N$ adalah peubah acak yang menyatakan banyak kegagalan yang terjadi dan $L_{i}$ adalah peubah acak yang menyatakan besar biaya yang dikeluarkan untuk pembetulan ke-i. Untuk kasus komponen adalah nonrepairable, disini diasumsikan harga per unit $(\ell)$ komponen tersebut tidak berubah sepanjang waktu, ekspektasi biaya garansi didefinisikan oleh

$$
E[A]=\ell E[N]
$$

\subsection{Proses Pembaruan Dua Dimensi}

Berdasarkan [3], [5], dan [6], model garansi dua dimensi dipengaruhi model kegagalan yang melibatkan proses pembaruan dua dimensi di bidang $[0, x) \times[0, y)$ sehingga ekspektasi biaya garansi di masa garansi $[0, x) \times[0, y)$ adalah $E[N]=M(x, y)$ dengan

$$
M(x, y)=H(x, y)+\int_{0}^{x} \int_{0}^{y} M(x-t, y-s) d H(t, s)
$$

\subsection{Metode Mean Value Theorem for Integrals (MeVTI) untuk menghitung $M(x, y)$}

Disini estimasi $M(x, y)$ pada (3) dilakukan secara numerik melalui metode mean value theorem for integrals (MeVTI) [1]. Sebelum menerapkan metode MeVTI, dilakukan perubahan peubah yaitu $a=x-t$ dan $b=y-s$ pada (3). Setelah itu, MeVTI pada ujung kiri diterapkan untuk memperoleh estimasi $M(x, y)$ yang selanjutnya dinyatakan oleh $\widehat{M}(x, y)$. Interval $[0, x)$ dan $[0, y)$ masing-masing dibagi sebanyak $n$ dan $m$ bagian sama panjang, $\Delta x=\frac{x}{n}$ dan $\Delta y=\frac{y}{m}$, sehingga diperoleh $n \times m$ persegi panjang $\left[x_{i-1}, x_{i}\right) \times\left[y_{j-1}, y_{j}\right)$ untuk $\quad x_{i}=i \Delta x, i=0,1,2, \ldots, n, y_{j}=j \Delta y, j=$ $0,1,2, \ldots, m$. Nilai $\widehat{M}(x, y)$ diperoleh melalui

$$
\widehat{M}\left(x_{i}, y_{j}\right)=\sum_{i=1}^{n} \sum_{j=1}^{m}\left[\left(1+\widehat{M}\left(x_{i-1}, y_{j-1}\right)\right) \Delta_{x_{i-1}}^{x_{i}} \Delta_{y_{i-1}}^{y_{i}} H(x-a, y-b)\right]
$$

dengan terlebih dahulu memperoleh

$$
\widehat{M}\left(x_{p}, y_{q}\right)=\sum_{i=1}^{p} \sum_{j=1}^{q}\left[\left(1+\widehat{M}\left(x_{i-1}, y_{j-1}\right)\right) \Delta_{x_{i-1}}^{x_{i}} \Delta_{y_{i-1}}^{y_{i}} H\left(x_{p}-a, y_{q}-b\right)\right] \text { (4) }
$$

untuk $p=0,1,2, \ldots, n-1, q=0,1,2, \ldots, m-1$ dan syarat awal $\widehat{M}(0,0)=M(0,0)=0, \quad \widehat{M}\left(0, y_{q}\right)=\widehat{M}\left(x_{p}, 0\right)=0$. Metode ini diusulkan oleh [1].

\subsection{Distribusi Bivariat}

Berdasarkan (3), ekspektasi biaya garansi di masa garansi $[0, x) \times[0, y)$, yaitu $M(x, y)$, melibatkan distribusi bivariat $H(x, y)$. Beberapa keluarga distribusi bivariat diusulkan dalam analisis garansi. Salah satu keluarga distribusi bivariat tersebut adalah distribusi bivariat Weibull yang diusulkan oleh Lu-Bhattacharyya pada [4] yang mana distribusi bivariat tersebut dinyatakan oleh fungsi survival bivariat berikut ini

$$
\bar{H}_{L B, \delta}(x, y)=\exp \left\{-\left[\left(\frac{x}{\beta_{1}}\right)^{\frac{\alpha_{1}}{\delta}}+\left(\frac{y}{\beta_{2}}\right)^{\frac{\alpha_{2}}{\delta}}\right]^{\delta}\right\}
$$

\subsection{Copula}

Copula (bivariat) adalah suatu fungsi distribusi bivariat dengan marginal-marginalnya berdistribusi seragam $[0,1]$. Copula $C$ didefinisikan oleh

$$
C(u, v)=\operatorname{Pr}[U \leq u, V \leq v]
$$

untuk $U$ dan $V$ berdistribusi seragam di [0,1]. Menurut Teorema Sklar pada [7], jika $H$ adalah fungsi distribusi bivariat dengan fungsi-fungsi distribusi marginal $F$ dan $G$, maka terdapat suatu copula $C$ untuk semua $(x, y)$ sedemikian hingga

$$
H(x, y)=C(F(x), G(y))
$$

Berdasarkan [7], berkaitan dengan suatu copula $C$, salah satu ukuran keterhubungan antara dua peubah acak yaitu Kendall's tau $(\tau)$ didefinisikan oleh

$$
\tau=4 \iint_{I^{2}} C(u, v) d C(u, v)-1
$$

\subsection{Copula Archimedean}

Keluarga copula Archimedean adalah fungsifungsi copula yang memiliki kekhasan yaitu memiliki satu parameter kebergantungan $(\theta)$ dan dapat dibentuk 
dari suatu fungsi pembangkit copula $\varphi$ [7]. Copula Archimedean (bivariat) didefinisikan oleh

$$
\varphi_{\theta}(C(u, v))=\varphi_{\theta}(u)+\varphi_{\theta}(v)
$$

Estimasi parameter copula Archimedean $(\theta)$ berdasarkan Kendall's tau $(\tau)$ pada (8) dapat diperoleh dengan mencari solusi persamaan berikut ini

$$
\tau=1+4 \int_{0}^{1} \frac{\varphi_{\theta}(t)}{\varphi_{\theta}^{\prime}(t)} d t
$$

seperti pada [7]. Selanjutnya dijelaskan empat jenis keluarga copula Archimedean berdasarkan [7].

Fungsi copula Clayton didefinisikan oleh

$$
C_{C, \theta}(u, v)=\left(u^{-\theta}+v^{-\theta}-1\right)^{-\frac{1}{\theta}}
$$

dengan $\theta \in(0, \infty)$. Fungsi pembangkit copula Clayton didefinisikan oleh

$$
\varphi_{\theta}(t)=\frac{1}{\theta}\left(t^{-\theta}-1\right)
$$

Parameter $\theta$ copula Clayton diperoleh dari persamaan (10) berdasarkan (12) yaitu

$$
\theta=\frac{2 \tau}{1-\tau}
$$

Fungsi copula Gumbel didefinisikan oleh

$$
C_{G, \theta}(u, v)=\exp \left(-\left[(-\ln u)^{\theta}+(-\ln v)^{\theta}\right]^{\frac{1}{\theta}}\right)
$$

dengan $\theta \in[1, \infty)$. Fungsi pembangkit copula Gumbel adalah

$$
\varphi_{\theta}(t)=(-\ln t)^{\theta}
$$

Parameter $\theta$ copula Gumbel melalui solusi persamaan (10) berdasarkan (15) adalah

$$
\theta=\frac{1}{1-\tau}
$$

Fungsi copula Frank didefinisikan oleh

$$
C_{F, \theta}(u, v)=-\frac{1}{\theta} \ln \left(1+\frac{\left(e^{-\theta u}-1\right)\left(e^{-\theta v}-1\right)}{e^{-\theta}-1}\right)
$$

dengan $\theta \in \mathbb{R} \backslash\{0\}$. Fungsi pembangkit copula Frank adalah

$$
\varphi_{\theta}(t)=-\ln \left(\frac{e^{-\theta t}-1}{e^{-\theta}-1}\right)
$$

Dengan mencari solusi persamaan (10) berdasarkan (18), parameter $\theta$ copula Frank adalah

$$
\tau=1-\frac{4\left(1-\theta^{-1} \int_{0}^{\theta} \frac{t}{e^{t}-1} d t\right)}{\theta}
$$

Copula AMH (Ali-Mikhail-Haq) dinyatakan oleh

$$
C_{A, \theta}=\frac{u v}{1-\theta(1-u)(1-v)}
$$

dengan $\theta \in[-1,1)$. Fungsi pembangkit copula $\mathrm{AMH}$ adalah

$$
\varphi_{\theta}(t)=\ln \left[\frac{1-\theta(1-t)}{t}\right]
$$

Berdasarkan (10) dan (21), parameter $\theta$ copula AMH diperoleh dari solusi persamaan

$$
\tau=\frac{3 \theta-2}{3 \theta}-\frac{2(1-\theta)^{2} \ln (1-\theta)}{3 \theta^{2}}
$$

Perolehan $\theta$ pada (19) dan (22) menggunakan metode bagi dua seperti dijelaskan pada [8].

\subsection{Goodness of Fit Test (Uji Kecocokan) untuk Distribusi Bivariat atau Copula}

Uji kecocokan diperlukan untuk mengetahui seberapa cocok distribusi bivariat atau copula mencerminkan perilaku data. Kecocokan data terhadap suatu fungsi distribusi bivariat atau copula bergantung pada nilai statistik terkecil Cramér-von Mises $\left(S_{n}\right)$ dari beberapa fungsi distribusi bivariat atau copula yang dicocokkan dengan dibantu simulasi parametric bootstrap [1]. Nilai $S_{n}$ tersebut diperoleh dari

$$
\begin{aligned}
S_{n} & =\sum_{i=1}^{n}\left[H_{e}\left(x_{i}, y_{i}\right)-H_{\widehat{\theta}}\left(x_{i}, y_{i}\right)\right]^{2} \\
& =\sum_{i=1}^{n}\left[C_{e}\left(F\left(x_{i}\right), G\left(y_{i}\right)\right)-H_{\widehat{\theta}}\left(F\left(x_{i}\right), G\left(y_{i}\right)\right)\right]^{2}
\end{aligned}
$$

dengan $\quad H_{e}\left(x_{i}, y_{i}\right)=C_{e}\left(F\left(x_{i}\right), G\left(y_{i}\right)\right)=\frac{\#\left(x \leq x_{i}, y \leq y_{i}\right)}{n+1}$ adalah fungsi distribusi bivariat empiris atau Copula empiris untuk data, $\left\{\left(x_{i}, y_{i}\right)\right\}, i=1,2, \ldots, n$. Fungsi $\#(x \leq$ $\left.x_{i}, y \leq y_{i}\right)$ menyatakan banyaknya data bivariat $\left\{\left(x_{i}, y_{i}\right)\right\}$ dengan $x \leq x_{i}$ dan $y \leq y_{i}$.

\subsection{Parametric Bootstrap untuk Ukuran Statistik Cramer-von Mises}

Ukuran statistik dan p-value Cramér-von Mises $\left(S_{n}\right)$ dapat diperoleh melalui metode simulasi parametric bootstrap [1]. Algoritma parametric bootstrap dijabarkan sebagai berikut:

Diketahui data bivariat sebanyak $n$ pasang yaitu $\left\{\left(x_{a}, y_{a}\right)\right\}, a=0,1,2,3, \ldots, n$. Untuk $N$ bilangan bulat positif sangat besar,

1. Bangkitkan $n$ sampel acak bivariat $\left\{\left(x_{i}, y_{i}\right)\right\}$ dengan $i=0,1,2, \ldots, n$ dari suatu distribusi bivariat $H_{\theta}(x, y)$ atau Copula $C_{\theta}(F(x), G(y))$, masing-masing terdapat di [7],

2. Hitung $H_{e}\left(x_{i}, y_{i}\right)=C_{e}\left(F\left(x_{i}\right), G\left(y_{i}\right)\right)=$ $\frac{\#\left(x_{a} \leq x_{i}, y_{a} \leq y_{i}\right)}{n+1}$ dengan $\#\left(x_{a} \leq x_{i}, y_{a} \leq y_{i}\right)$ adalah banyak data bivariat $\left\{\left(x_{a}, y_{a}\right)\right\}$ dengan $x_{a} \leq x_{i}$ dan $y_{a} \leq y_{i}$,

3. Untuk $j=1$, hitung

$$
\begin{aligned}
s_{n, j}^{*} & =\sum_{i=1}^{n}\left[H_{e}\left(x_{i}, y_{i}\right)-H_{\theta}\left(x_{i}, y_{i}\right)\right]^{2} \\
& =\sum_{i=1}^{n}\left[C_{e}\left(F\left(x_{i}\right), G\left(y_{i}\right)\right)-C_{\theta}\left(F\left(x_{i}\right), G\left(y_{i}\right)\right)\right]^{2}
\end{aligned}
$$

4. Untuk $j=j+1$, ulangi poin 1 sampai poin 3 , ke poin 5 jika $j=N+1$,

5. Hitung $p$-value, $\frac{\#\left(s_{n, j}^{*}>s_{n}\right)}{N}$ atau $\sum_{j=1}^{N}\left(\frac{I\left(s_{n, j}^{*}>s_{n}\right)}{N}\right)$, yang mana $I\left(s_{n, j}^{*}>s_{n}\right)$ adalah fungsi bernilai 1 untuk nilai $s_{n, j}^{*}>s_{n}$.

\subsection{Metode Penelitian}

Disini dilakukan pengolahan data yang dimiliki melalui langkah-langkah berikut:

1. Menghitung umur komponen oil filter dalam satuan hari yang dihitung dari tanggal saat reparasi dikurangi tanggal reparasi sebelumnya atau tanggal beli mobil jika reparasi pertama kali, 
2. Menghitung penggunaan komponen oil filter dalam satuan kilometer (diperoleh dari odometer) yang dihitung dari saat reparasi dikurangi kilometer saat reparasi sebelumnya atau o (nol) kilometer jika reparasi pertama kali,

3. Mengubah data umur (dalam hari) kegagalan pertama komponen oil filter ke dalam satuan tahun (dibagi 360) lalu disebut data marginal $X_{1}$,

4. Mengubah data penggunaan $(\mathrm{km})$ kegagalan pertama komponen oil filter ke dalam satuan per 10000 kilometer lalu disebut data marginal $Y_{1}$.

Setelah dilakukan pengolahan data, langkah selanjutnya adalah analisis data marginal $X_{1}$ dan $Y_{1}$ berdasarkan langkah-langkah berikut:

i. Mencari distribusi kegagalan dari masing-masing data marginal $X_{1}$ dan $Y_{1}$,

ii. Menghitung keterhubungan data marginal $X_{1}$ dan $Y_{1}$ melalui Kendall's tau,

iii. Goodness of fit test marginal dilakukan untuk:

a. Estimasi parameter distribusi marginal $X_{1}$ dan $Y_{1}$ menggunakan maximum log-likelihood estimation (MLE) seperti pada [9],

b. Uji kecocokan distribusi marginal $X_{1}$ dan $Y_{1}$ menggunakan uji Kolmogorov-Smirnov seperti dijabarkan oleh [9],

Langkah selanjutnya adalah estimasi parameter copula Archimedean yang dilakukan berdasarkan Kendall's tau. Setelah diperoleh pilihan distribusi marginal $X_{1}$ dan $Y_{1}$ pada langkah (iii) dan parameter distribusi bivariat atau copula Archimedean, maka selanjutnya melakukan uji kecocokan berdasarkan statistik Cramér-von Mises untuk kecocokan modelmodel distribusi bivariat atau copula Archimedean.

\section{HASIL DAN PEMBAHASAN}

\section{1. Data Marginal}

Setelah melalui pengolahan, data kegagalan pertama oil filter dilihat dari umur $X_{1}$ (tahun) dan penggunaan $Y_{1}(10000 \mathrm{~km})$ disajikan pada Gambar 1.

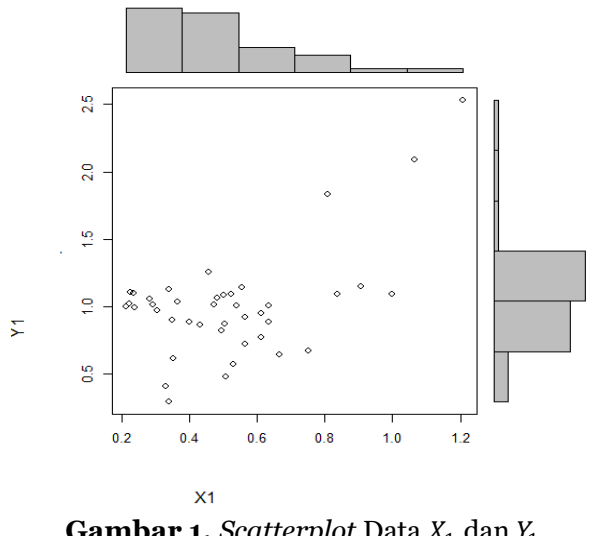

Gambar 1 merupakan scatterplot $\left(X_{1}, Y_{1}\right)$ dari data umur $X_{1}$ dan penggunaan $Y_{1}$ komponen oil filter saat kegagalan pertama. Histogram masing-masing marginal ditampilkan sebelah atas (umur) dan kanan (penggunaan) scatterplot pada Gambar 1.

\section{2. Goodness of Fit Test Marginal $X_{1}$ dan $Y_{1}$}

Bagian ini diberikan taksiran parameterparameter (melalui MLE) dan uji kecocokan Kolmogorov-Smirnov ( $p$-value) untuk pilihan distribusi-distribusi marginal (untuk peubah acak kontinu tak negatif) berdasarkan data $X_{1}$ dan $Y_{1}$ yang disajikan pada Tabel 1.

Tabel 1. Parameter dan Uji Kecocokan KolmogorovSmirnov ( $p$-value) Distribusi Marginal Data

\begin{tabular}{|c|c|c|c|c|}
\hline Dist. & Marg. & \multicolumn{2}{|c|}{ Parameter } & p-value (KS) \\
\hline Weibull & \multirow{4}{*}{$X_{1}$} & $\widehat{\alpha_{1}}=2.645$ & $\widehat{\beta_{1}}=0.566$ & 0.9401 \\
\hline Lognorm. & & $\widehat{\mu_{1}}=-0.751$ & $\widehat{\sigma_{1}}=0.441$ & 0.8992 \\
\hline Gamma & & $\widehat{\alpha_{1}}=4.788$ & $\widehat{\beta_{1}}=0.109$ & 0.9340 \\
\hline Eksp. & & \multicolumn{2}{|c|}{$\widehat{\lambda_{1}}=1.922$} & $1.4 \times 10^{-4}$ \\
\hline Weibull & \multirow{4}{*}{$Y_{1}$} & $\widehat{\alpha_{2}}=3.153$ & $\widehat{\beta_{2}}=1.088$ & 0.0603 \\
\hline Lognorm. & & $\widehat{\mu_{2}}=-0.064$ & $\widehat{\sigma_{2}}=0.376$ & 0.0800 \\
\hline Gamma & & $\widehat{\alpha_{2}}=6.380$ & $\widehat{\beta_{2}}=0.158$ & 0.0376 \\
\hline Eksp. & & \multicolumn{2}{|c|}{$\widehat{\lambda_{2}}=0.947$} & $2.6 \times 10^{-5}$ \\
\hline
\end{tabular}

Berdasarkan Tabel 1, keluarga distribusi Eksponensial gagal untuk memodelkan marginal $X_{1}$ dan $Y_{1}$ karena hipotesis $H_{0}$ ditolak di tingkat signifikansi o.05. Begitu pula distribusi Gamma gagal untuk memodelkan marginal $Y_{1}$ karena hipotesis $H_{0}$ ditolak di tingkat signifikansi o.05. Meski begitu, model copula Archimedean untuk marginal-marginal tersebut tetap akan diestimasi. Copula Archimedean (Clayton, Gumbel, Frank, dan AMH) diestimasi untuk kombinasi marginal $X_{1}$ : Weibull, Lognormal, Gamma, dan Eksponensial; dan $Y_{1}$ : Weibull, Lognormal, Gamma, dan Eksponensial. Dari sini, akan diestimasi distribusi bivariat Weibull Lu-Bhattacharyya karena di tingkat signifikansi 0.05, distribusi Weibull mampu memodelkan marginal $X_{1}$ dan $Y_{1}$.

\section{3. Kendall's Tau dari Data $X_{1}$ dan $Y_{1}$} Kendall's tau data $X_{1}$ dan $Y_{1}$ tertampil di Tabel 2.

Tabel 2. Ukuran Keterhubungan Kendall's Tau dari Data Marginal $X_{1}$ dan $Y_{1}$

\begin{tabular}{cc}
\hline Marginal & Kendall's Tau \\
\hline $\boldsymbol{X}_{\mathbf{1}}$ dan $\boldsymbol{Y}_{\mathbf{1}}$ & $\tau=0.0880$ \\
\hline
\end{tabular}

\section{4. Estimasi Parameter Distribusi Bivariat Weibull Lu-Bhattacharyya (LB)}

Fungsi survival bivariat Lu-Bhattacharyya pada (5) merupakan copula Gumbel dengan marginalmarginalnya adalah fungsi survival Weibull. Parameter distribusi bivariat Weibull Lu-Bhhattacharyya yang bersesuaian dengan parameter copula Gumbel adalah $\delta=1 / \theta$. Sehingga parameter distribusi bivariat Weibull Lu-Bhhattacharyya $\delta$ dapat diperoleh dengan terlebih dahulu mengetahui parameter copula Gumbel.

\section{5. Estimasi Parameter Copula Archimedean}

Estimasi parameter copula Archimedean yang terdiri dari copula Clayton, Gumbel, Frank, dan AMH diperoleh dengan menggunakan ukuran keterhubungan Kendall's tau. Parameter distribusi bivariat Weibull LuBhattacharyya (LB) diperoleh berdasarkan parameter 
copula Gumbel. Tabel 3 berisi estimasi parameterparameter tersebut.

Tabel 3. Parameter Copula Archimedean dan Distribusi Bivariat Weibull LB

\begin{tabular}{|c|c|c|c|c|}
\hline \multicolumn{3}{|c|}{$\widehat{\boldsymbol{\theta}}$} & & $\widehat{\boldsymbol{\delta}}$ \\
\hline Clayton & Gumbel & Frank & AMH & Biv. Wei. LB \\
\hline 0.193 & 1.096 & 0.797 & 0.358 & 0.912 \\
\hline
\end{tabular}

\section{6. Uji Kecocokan Distribusi Biv. Weibull LB} dan Copula Archimedean

Uji kecocokan model distribusi bivariat dan copula dilakukan berdasarkan parameter di Tabel 3 dan marginal-marginal di Tabel 1 melalui statistik Cramèrvon Mises $S_{n}$ dan $p$-value dari parametric bootstrap. Tabel 4 berisi statistik $\widehat{S_{n}}$ model-model tersebut.

Tabel 4. Statistik Cramér-von Mises $\widehat{S_{n}}$ Model-Model Distribusi Bivariat

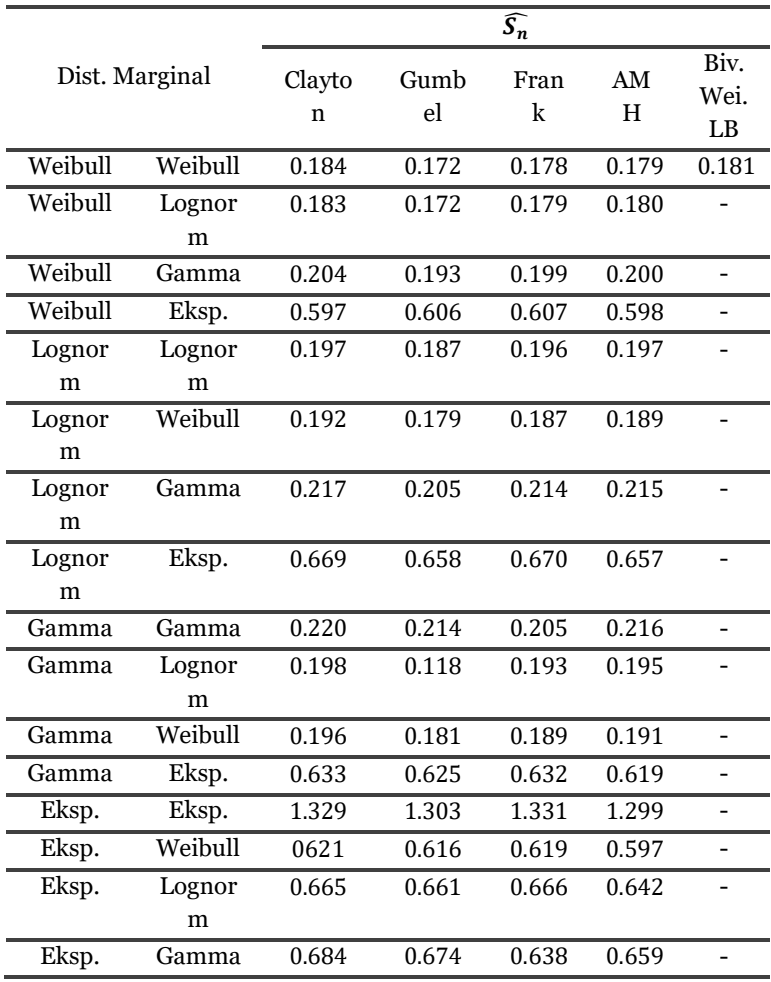

Langkah selanjutnya adalah melakukan simulasi parametric bootstrap sebanyak 100 kali untuk menaksir rata-rata $p$-value dan seberapa banyak $H_{0}$ diterima dalam pengulangan tersebut. Tabel 5 menunjukkan jumlah $H_{0}$ yang diterima, rata-rata nilai $p$-value, dan standar deviasi $p$-value setelah dilakukan pengulangan sebanyak 100 kali.

Setelah dilakukan pengulangan dan untuk tingkat signifikansi 0.05, model distribusi bivariat atau copula yang memiliki rata-rata $p$-value terbesar adalah model copula Clayton dengan $\hat{\theta}=0.1930$ yang memodelkan marginal $X_{1} \sim$ Weibull $\left(\widehat{\alpha_{1}}=2.6446, \widehat{\beta_{1}}=0.5663\right)$ dan marginal $\quad Y_{1} \sim \operatorname{Lognormal}\left(\widehat{\mu_{2}}=-0.0636, \widehat{\sigma_{2}}=0.3761\right)$ dengan fungsi distribusi, densitas, dan contour model tersebut disajikan pada Gambar 2.

\section{7. Ekspektasi Banyak Kegagalan dan Estimasi Biaya Garansi}

Setelah diperoleh model terbaik adalah model copula Clayton dengan marginal $X_{1}$ Weibull dan $Y_{1}$ Lognormal, maka ekspektasi banyak kegagalan di dua dimensi untuk oil filter bergaransi polis FRW dengan strategi penggantian dapat dihitung. Ekspektasi banyak kegagalan oil filter pada masa garansi $[0, k) \times[0, l)$ polis FRW dengan strategi penggantian dinyatakan oleh

$$
E\left[N_{2}(k, l)\right]=\widehat{M}_{C_{C}, \widehat{\theta}}(k, l)
$$

dengan

$$
\begin{aligned}
\widehat{M}_{C_{c}, \widehat{\theta}}(k, l)=\sum_{i=1}^{n} \sum_{j=1}^{m} & {\left[\left(1+\widehat{M}\left(x_{i-1}, y_{j-1}\right)\right)\right.} \\
\times & \Delta_{x_{i-1}}^{x_{i}} \Delta_{y_{j-1}}^{y_{j}} C_{C, \widehat{\theta}}(F(x-a), G(y \\
& -b))](26)
\end{aligned}
$$

serta $C_{C, \widehat{\theta}}(u, v)$ seperti pada (11) dan $\hat{\theta}=0.1930$ untuk $F$ dan $G$ berurutan marginal:

$$
\begin{gathered}
X_{1} \sim \operatorname{Weibull}\left(\widehat{\alpha_{1}}=2.6446, \widehat{\beta_{1}}=0.5663\right) \\
Y_{1} \sim \operatorname{Lognormal}\left(\widehat{\mu_{2}}=-0.0636, \widehat{\sigma_{2}}=0.3761\right)
\end{gathered}
$$
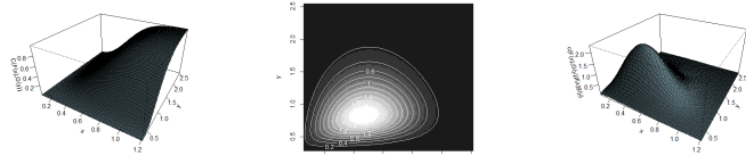

Fungsi Distribusi Contour Densitas Fungsi Densitas

\begin{tabular}{|c|c|c|c|c|c|c|}
\hline Marg. & Hasil & $\begin{array}{c}\mathrm{AM} \\
\mathrm{H}\end{array}$ & $\begin{array}{c}\text { Clayto } \\
\mathrm{n}\end{array}$ & $\begin{array}{c}\text { Fran } \\
\mathrm{k}\end{array}$ & $\begin{array}{c}\text { Gumbe } \\
1\end{array}$ & $\begin{array}{c}\text { Biv. } \\
\text { Wei. } \\
\text { LB }\end{array}$ \\
\hline \multirow{3}{*}{$\begin{array}{l}\text { Weibull } \\
\text { Weibull }\end{array}$} & $\mathrm{H}_{0} \mathrm{ac}$ & 100 & 100 & 100 & 100 & 100 \\
\hline & c & & & & & \\
\hline & p-val & 0.679 & 0.704 & 0.671 & 0.630 & 0.668 \\
\hline \multirow{3}{*}{$\begin{array}{l}\text { Weibull } \\
\text { Lognorm }\end{array}$} & $\mathrm{H}_{0} \mathrm{ac}$ & 100 & 100 & 100 & 100 & - \\
\hline & $\mathrm{c}$ & & & & & \\
\hline & p-val & 0.790 & 0.814 & 0.786 & 0.754 & - \\
\hline \multirow{3}{*}{$\begin{array}{l}\text { Weibull } \\
\text { Gamma }\end{array}$} & $\mathrm{H}_{0} \mathrm{ac}$ & 100 & 100 & 100 & 100 & - \\
\hline & c & & & & & \\
\hline & p-val & 0.712 & 0.738 & 0.707 & 0.659 & - \\
\hline \multirow{3}{*}{$\begin{array}{l}\text { Weibull } \\
\text { Eksp. }\end{array}$} & $\mathrm{H}_{0} \mathrm{ac}$ & 100 & 100 & 100 & 100 & - \\
\hline & $\mathrm{c}$ & & & & & \\
\hline & p-val & 0.670 & 0.742 & 0.617 & 0.653 & - \\
\hline \multirow{3}{*}{$\begin{array}{c}\text { Lognorm } \\
\text {. } \\
\text { Lognorm }\end{array}$} & $\mathrm{H}_{0} \mathrm{ac}$ & 100 & 100 & 100 & 100 & - \\
\hline & c & & & & & \\
\hline & p-val & 0.635 & 0.668 & 0.629 & 0.599 & - \\
\hline \multirow{4}{*}{$\begin{array}{c}\text { Lognorm } \\
\text { Weibull }\end{array}$} & & & & & & \\
\hline & $\mathrm{H}_{0} \mathrm{ac}$ & 100 & 100 & 100 & 100 & - \\
\hline & c & & & & & \\
\hline & p-val & 0.543 & 0.568 & 0.535 & 0.498 & - \\
\hline \multirow{3}{*}{$\begin{array}{c}\text { Lognorm } \\
\cdot \\
\text { Gamma }\end{array}$} & $\mathrm{H}_{0} \mathrm{ac}$ & 100 & 100 & 100 & 100 & - \\
\hline & $\mathrm{c}$ & & & & & \\
\hline & p-val & 0.554 & 0.587 & 0.551 & 0.506 & - \\
\hline \multirow{3}{*}{$\begin{array}{c}\text { Lognorm } \\
\text { Eksp. }\end{array}$} & $\mathrm{H}_{0} \mathrm{ac}$ & 100 & 100 & 100 & 100 & - \\
\hline & c & & & & & \\
\hline & p-val & 0.479 & 0.556 & 0.460 & 0.425 & - \\
\hline
\end{tabular}
Gambar 2. Bivariat Copula Clayton $\hat{\theta}=0.1930$ untuk Marginal $X_{1} \sim$ Weibull $\left(\widehat{\alpha_{1}}=2.6446, \widehat{\beta_{1}}=0.5663\right) \mathrm{dan}$ $Y_{1} \sim \operatorname{Lognormal}\left(\widehat{\mu_{2}}=-0.0636, \widehat{\sigma_{2}}=0.3761\right)$

Tabel 5. Hasil Pengulangan Parametric Bootstrap 100 Kali untuk p-value Cramér-von Mises $\widehat{S_{n}}$ 


\begin{tabular}{|c|c|c|c|c|c|c|}
\hline \multirow{2}{*}{$\begin{array}{c}\text { Gamma } \\
\text { Lognorm } \\
.\end{array}$} & $\begin{array}{c}\mathrm{H}_{0} \mathrm{ac} \\
\mathrm{c}\end{array}$ & 100 & 100 & 100 & 100 & - \\
\hline & p-val & 0.723 & 0.742 & 0.718 & 0.688 & - \\
\hline \multirow{3}{*}{$\begin{array}{l}\text { Gamma } \\
\text { Weibull }\end{array}$} & $\mathrm{H}_{0} \mathrm{ac}$ & 100 & 100 & 100 & 100 & - \\
\hline & $\mathrm{c}$ & & & & & \\
\hline & p-val & 0.066 & 0.661 & 0.641 & 0.601 & - \\
\hline \multirow{3}{*}{$\begin{array}{l}\text { Gamma } \\
\text { Gamma }\end{array}$} & $\mathrm{H}_{0} \mathrm{ac}$ & 100 & 100 & 100 & 100 & - \\
\hline & c & & & & & \\
\hline & p-val & 0.660 & 0.673 & 0.654 & 0.610 & - \\
\hline \multirow{3}{*}{$\begin{array}{c}\text { Gamma } \\
\text { Eksp. }\end{array}$} & $\mathrm{H}_{0} \mathrm{ac}$ & 100 & 100 & 100 & 100 & - \\
\hline & $\mathrm{c}$ & & & & & \\
\hline & p-val & 0.626 & 0.700 & 0.608 & 0.575 & - \\
\hline \multirow{3}{*}{$\begin{array}{l}\text { Eksp. } \\
\text { Eksp. }\end{array}$} & $\mathrm{H}_{0} \mathrm{ac}$ & 31 & 100 & 5 & 2 & - \\
\hline & $\mathrm{c}$ & & & & & \\
\hline & p-val & 0.046 & 0.081 & 0.039 & 0.037 & - \\
\hline \multirow{3}{*}{$\begin{array}{c}\text { Eksp. } \\
\text { Weibull }\end{array}$} & $\mathrm{H}_{0} \mathrm{ac}$ & 100 & 100 & 100 & 100 & - \\
\hline & $\mathrm{c}$ & & & & & \\
\hline & p-val & 0.483 & 0.556 & 0.474 & 0.495 & - \\
\hline \multirow{3}{*}{$\begin{array}{c}\text { Eksp. } \\
\text { Lognorm }\end{array}$} & $\mathrm{H}_{0} \mathrm{ac}$ & 100 & 100 & 100 & 100 & - \\
\hline & $\mathrm{c}$ & & & & & \\
\hline & p-val & 0.421 & 0.491 & 0.407 & 0.402 & - \\
\hline \multirow{3}{*}{$\begin{array}{c}\text { Eksp. } \\
\text { Gamma }\end{array}$} & $\mathrm{H}_{0} \mathrm{ac}$ & 100 & 100 & 100 & 100 & - \\
\hline & $\mathrm{c}$ & & & & & \\
\hline & p-val & 0.335 & 0.413 & 0328 & 0.320 & - \\
\hline
\end{tabular}

Selanjutnya, ekspektasi tersebut ditampilkan pada Tabel 6. Terlihat pada Tabel 6 bahwa banyak kegagalan oil filter meningkat seraya umur dan penggunaan meningkat. Gambar 3 merupakan grafik peningkatan ekspektasi banyak kegagalan oil filter berdasarkan penggunaan untuk tiap umur tertentu. Dalam hal ini, 0,5 tahun setara dengan 6 bulan. Sebagai contoh, bilangan 1,5 tahun berarti 1 tahun 6 bulan.

Tabel 6. Ekspektasi Banyak Kegagalan berdasarkan Model pada (26)

\begin{tabular}{|c|c|c|c|c|c|c|c|}
\hline & \multicolumn{6}{|c|}{ Batas Penggunaan $(10000 \mathrm{~km})$} \\
\hline & & 0.5 & 1 & 1.5 & 2 & 2.5 & 3 \\
\hline \multirow{5}{*}{ 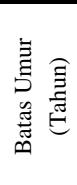 } & 0.5 & 0.032 & 0.311 & 0.474 & 0.524 & 0.539 & 0.543 \\
\hline & 1 & 0.047 & 0.566 & 0.983 & 1.261 & 1.428 & 1.506 \\
\hline & 1.5 & 0.047 & 0.574 & 1.055 & 1.518 & 1.906 & 2.185 \\
\hline & 2 & 0.047 & 0.574 & 1.061 & 1.554 & 2.032 & 2.471 \\
\hline & 2.5 & 0.047 & 0.574 & 1.061 & 1.556 & 2.049 & 2.536 \\
\hline
\end{tabular}

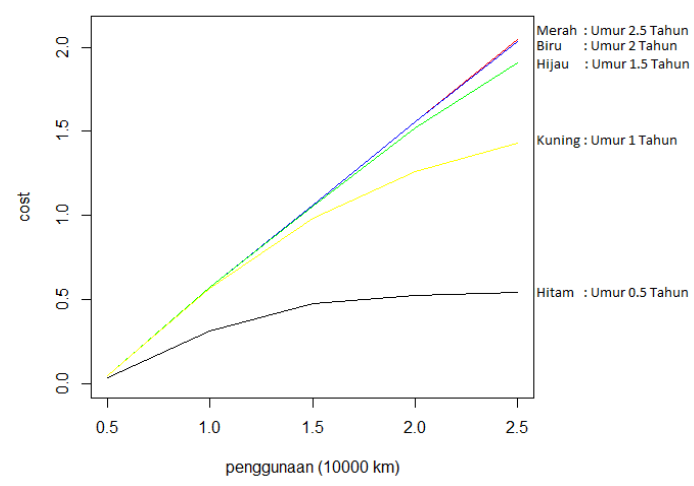

Gambar 3. Grafik Estimasi Biaya Garansi Oil Filter berdasarkan Penggunaan untuk Umur Tertentu

Misalkan harga oil filter baru adalah seharga $\ell=$ 30000 Rupiah, maka Tabel 7 berisi estimasi biaya garansi oil filter mobil untuk masa garansi dua dimensi tertentu. Terlihat pada Tabel 7 bahwa estimasi biaya (dalam Rupiah) garansi oil filter mobil meningkat seraya umur dan penggunaan meningkat.

Tabel 7. Estimasi Biaya (dalam Rupiah) Garansi Dua Dimensi Oil Filter berdasarkan Model pada (26)

\begin{tabular}{cccccccc}
\hline & \multicolumn{6}{c}{ Batas Penggunaan (10000 km) } \\
\cline { 2 - 8 } & 0.5 & 1 & 1.5 & 2 & 2.5 & 3 \\
\hline 0.5 & 966 & 9342 & 14232 & 15735 & 16173 & 16293 \\
\hline & 1 & 1404 & 16986 & 29481 & 37836 & 42828 & 45192 \\
\hline
\end{tabular}

\section{KESIMPULAN}

Penelitian ini bertujuan untuk memperoleh model dan biaya garansi dua dimensi polis non-renewing free replacement warranty dengan strategi penggantian untuk oil filter mobil. Tujuan penelitian ini telah diperoleh dua hal. Pertama, model biaya garansi dua dimensi tersebut melibatkan copula Clayton dengan parameter $\hat{\theta}=0.1930$ untuk marginal umur $X_{1} \sim$ Weibull $\left(\widehat{\alpha_{1}}=2.6446, \widehat{\beta_{1}}=0.5663\right)$ dan penggunaan $Y_{1} \sim \operatorname{Lognormal}\left(\widehat{\mu_{2}}=-0.0636, \widehat{\sigma_{2}}=0.3761\right)$. Model ini diperoleh melalui tahapan-tahapan: estimasi parameter distribusi bivariat berdasarkan Kendall's tau, seleksi model distribusi bivariat melalui uji statistik Cramèrvon Mises $S_{n}$, dan $p$-value statistik tersebut melalui simulasi parametric bootstrap. Pemodelan melibatkan copula mengakibatkan model-model distribusi bivariat semakin banyak pilihan atau bervariasi sesuai dengan kebutuhan untuk memodelkan data yang memiliki marginal-marginal berbeda keluarga distribusi. Kedua, berdasarkan model biaya garansi yang telah diperoleh, ekspektasi banyak kegagalan oil filter di masa garansi dua dimensi tertentu dapat dihitung dengan menggunakan metode mean value theorem for integrals. Biaya garansi dua dimensi polis nonrenewing free replacement warranty dengan strategi penggantian oil filter mobil dapat dihitung. Biaya tersebut merupakan perkalian dari harga oil filter dengan ekspektasi banyak kegagalan. Ekspektasi banyak kegagalan ditampilkan pada Tabel 6. Sedangkan estimasi biaya garansi ditampilkan pada Tabel 7 .

\section{REFERENSI}

[1] L. R. Sasongko, "Copula untuk Memodelkan Kegagalan Dua Dimensi pada Produk Bergaransi dengan Strategi Penggantian," M.Si. tesis, Program Pascasarjana Magister Aktuaria, Institut Teknologi Bandung, Bandung, 2014.

[2] W. R. Blischke, M. R. Karim, dan D. N. P. Murthy, Warranty Data Collection and Analysis, London: Springer Series in Reliability Eng., 2011, bab 2.

[3] J. Baik, D. N. P. Murthy, dan N. Jack, "TwoDimensional Failure Modelling with Minimal Repair," Naval Research Logistics, vol. 51, no. 3 , pp. 345-362, Nov. 2004.

[4] J. C. Lu, dan G. K. Bhattacharyya, "Some New Contructions of Bivariate Weibull Models," Ann. 
Inst. Statist. Math, vol. 42, no. 3, pp. 543-559, Sept. 1990.

[5] J. J. Hunter, J. J., "Renewal Theory in Two Dimensions: Basic Results," Adv. Appl. Probab, vol. 6, pp. 376-391, 1974.

[6] S. C. Yang, "A Bivariate Renewal Process And Its Application in Maintenance Policies," Ph.D. Dissertation, Faculty of Virginia Polytechnic Inst. and State University, Blacksburg-Virginia, 1999.

[7] R. B. Nelsen, An Introduction to Copulas, New York: Springer Series in Statistics, 2006.

[8] D. B. Nugroho, "Metode Numerik", unpublished.

[9] Y. K. Tse, Nonlife Actuarial Models: Theory, Methods, and Evaluation, New York: Cambridge University Press, 2009.

\section{Lampiran A. Fungsi Distribusi Univariat}

Pada bagian ini akan diberikan fungsi distribusi univariat yang digunakan dan dituliskan dalam penelitian ini. Misalkan $X$ adalah peubah acak kontinu dengan fungsi distribusi $F_{X}$.

1. Lognormal dua parameter, $X \sim \operatorname{Lognormal}(\sigma, \mu)$,

$$
F_{X}(x)=\frac{1}{\sigma \sqrt{2 \pi}} \int_{0}^{x} \frac{1}{t} \exp \left(-\frac{(\ln t-\mu)^{2}}{2 \sigma^{2}}\right) d t
$$

2. Weibull dua parameter, $X \sim \operatorname{Weibull}(\alpha, \beta)$,

$$
F_{X}(x)=1-\exp \left(-\left(\frac{x}{\beta}\right)^{\alpha}\right)
$$

3. Gamma dua parameter, $X \sim \operatorname{Gamma}(\alpha, \beta)$,

$$
F_{X}(x)=\frac{\beta^{\alpha}}{\Gamma(\alpha)} \int_{0}^{x} t^{\alpha-1} \exp (-\beta t) d t
$$

4. Eksponensial satu parameter, $X \sim \operatorname{Eksp} .(\lambda)$,

$$
F_{X}(x)=1-\exp (-\lambda x) \text {. }
$$

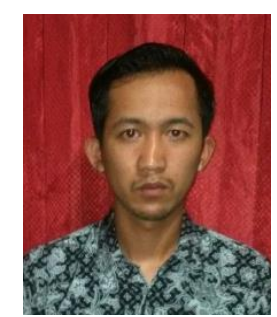

Nur Rohman lahir dan tinggal di Getasan, Kab. Semarang.

Dia masih menempuh pendidikan tinggi di Program Studi Matematika, Fakultas Sains dan Matematika, Universitas Kristen Satya Wacana (UKSW) Salatiga. Tahun 2018 adalah tahun terakhir ia menempuh studi. Makalah ini merupakan hasil dipublikasikan. penelitian skripsinya yang

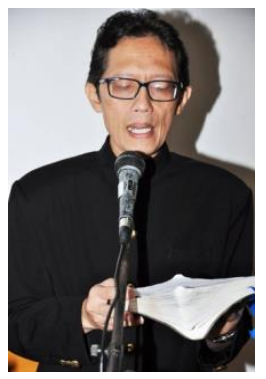

Tundjung Mahatma lahir di Salatiga, Indonesia dan tinggal di sana sampai dengan kini. Gelar Sarjana Pendidikan diperolehnya dari Universitas Kristen Satya Wacana (UKSW) Salatiga, dan pada 1990/1991 bertugas studi dan mendapatkan Postgraduate Diploma in Computing dari University of Essex, Inggris. Pada 2007 dia memperoleh gelar Master Ilmu Komputer (M.Kom.) dari Universitas Gadjah Mada, Yogyakarta.

Dia telah bekerja pada unit-unit yang berkenaan dengan Teknologi Informasi di UKSW, lalu pada tahun 2000 mengajar secara penuh di Program Studi Matematika, Fakultas Sains dan Matematika, UKSW.

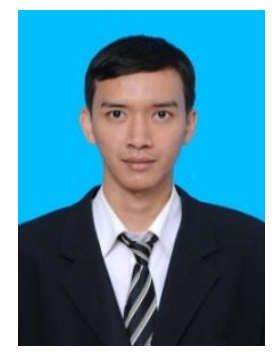

Leopoldus Ricky Sasongko lahir di Ketapang, Kalimantan Barat, pada tanggal 14 November 1989. Pada tahun 2011, gelar Sarjana Sains (S.Si) diperoleh dari Universitas Kristen Satya Wacana (UKSW) Salatiga. Gelar Magister Sains (M.Si) didapat dari Program Pascasarjana Magister Aktuaria, Institut Teknologi Bandung (ITB), pada tahun 2014.

Ia bekerja di UKSW sejak tahun 2011 sebagai Calon Pengajar Akademik (Dosen) di Program Studi Matematika, Fakultas Sains dan Matematika, UKSW. Saat ini, ia menjadi Pengajar Akademik Tetap di UKSW.

Sasongko, M.Si, merupakan salah satu anggota Asosiasi Matematikawan Indonesia, IndoMS. Bidang penelitian yang digeluti adalah Matematika Aktuaria dan Garansi (Warranty). Salah satu makalah hasil penelitian adalah The Estimation of Renewal Functions Using the Mean Value Theorem for Integrals (MeVTI) Method yang terpublikasi di Jurnal Matematika dan Aplikasi deCartesiaN, Universitas Sam Ratulangi (UNSRAT). 